\title{
Errata
}

\section{Terminologia Anatômica em Ortopedia}

No vol. 43(4), página 105, na Atualização “Terminologia Anatômica em Ortopedia", os autores solicitam a correção de erro de digitação seguinte:

Onde se lê:

\section{Tornozelo/Pé}

Art. intermetacarpeanas

Art. metacarpofalangianas

Art. intermetacarpais

Art. metacarpofalângicas

\section{Leia-se:}

Tornozelo/Pé
A ressonância magnética e a artrorressonância magnética na lesão labral e condral do quadril

No vol. 43(6), página 217, no artigo "A ressonância magnética e a artrorressonância magnética na lesão labral e condral do quadril: comparação com achados na artroscopia", solicita-se a correção do nome de um dos autores: onde se lê Francisco José Berral de la Rosa, leia-se Francisco José Berral. 